\title{
Dose Response Study of a Novel Gold-Manganese Oxide Nano-Composite in an In Vivo Murine Model
}

\author{
Anupam Nath ${ }^{1}$, Ramkrishna Pal ${ }^{1}$, Leichombam Mohindro Singh ${ }^{1}$, Himadri Saikia ${ }^{1}$, Hasimur Rahaman ${ }^{2}$, \\ Sujit Kumar Ghosh ${ }^{2}$, Ritwik Mazumder ${ }^{3}$, Mahuya Sengupta ${ }^{1 *}$ \\ ${ }^{1}$ Department of Biotechnology, ${ }^{2}$ Department of Chemistry, ${ }^{3}$ Department of Economics, Assam University, Silchar, Assam, India.
}

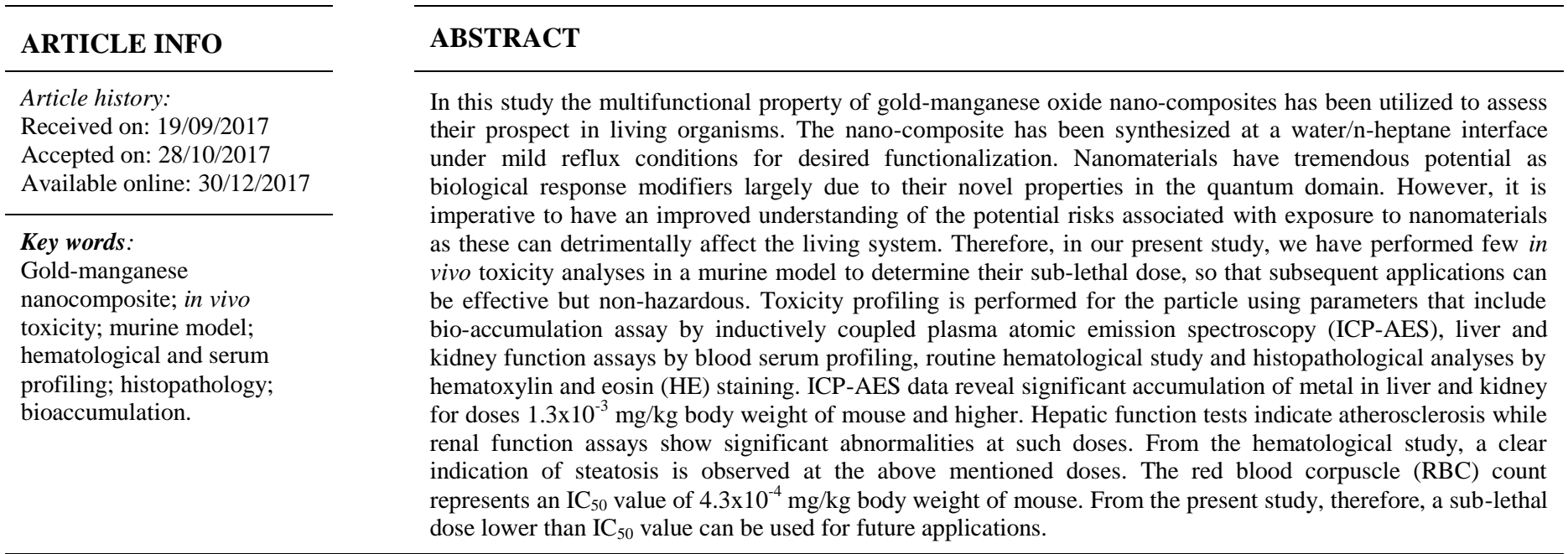

\section{INTRODUCTION}

Gold particles of size ranging from 15 to $198 \mathrm{~nm}$ showed that their permeation relies on the size of the particles and the duration of exposure to them. It was also resolved that particles having size of about $15 \mathrm{~nm}$ could permeate to a greater extent than the particles with larger dimensions (Sonavane et al., 2008). Gold nanoparticles (AuNPs) are being used in the field of biology since many years for their catalytic property as well as for their surface plasmon resonance (SPR) that can be used to detect particles inside the cells in real time (Pal et al., 2016). As this SPR property, a surface phenomenon, relies on the incidence of far infra-red radiation that can be detected visually, it is understandable that this technique can be used for studying

\footnotetext{
* Corresponding Author

Email: senguptamahuya35 @ gmail.com
}

surface monolayers but not cells under in vivo condition. For study of cells in a live tissue (in vivo), one way is to use a nanomaterial having a magnetic resonance imaging (MRI) signature. To harness the catalytic property of AuNPs with that of a magnetic nanoparticle, in the present study, we have used a nano-composite of manganese oxide nanoparticle coupled with gold nanoparticle in the ratio of 9:1 (w/w) (Rahaman et al., 2014) for their toxicity profiling in a murine model. In recent times, manganese oxide and other magnetic particles are gaining importance for their role as a contrasting agent in MRI which is an ideal technique for in vivo imaging. This property of such particles is thought to be due to their magnetic properties corresponding to their size (Huh et al., 2005). There are quite a few reports in recent times where gold nanoparticles are being coupled with these magnetic particles to produce multifunctional nano-composites (Yu et al., 2005; Mokari et al., 2004; Shi et al., 2006). 
Materials at nano scale respond to a greater extent than their bulkier counterparts when applied at equal mass dose (Johnston et al., 2010). This exciting property of nanoparticles is most likely due to their difference in surface to volume ratio with that of bulk materials (Johnston et al., 2009). Undeniably, due to this, their use is gaining an edge over conventional bulk materials at a very exciting pace. Nanoparticles are now also being extensively used in the field of medicine that includes targeted drug delivery and therapy (Soppimath et al., 2001), wound dressing and healing (Chen et al., 2006), as anti-microbial agents, bio-imaging using labeling agents and so on. As such, it is extremely necessary to examine their potential hazards upon exposure to living beings because of their high reactivity and wide distribution in the living system (Maynard et al., 2006). The characteristic properties of metal nanoparticles that are responsible for affecting the living systems either in a positive or in a negative way, cannot be extrapolated from the properties shown by their larger counterparts or bulk materials (Johnston et al., 2009). Therefore, we have systematically assessed the toxicity of the said nano-composite upon exposure in a murine model over a period of 28 days.

For bio-distribution and accumulation study, we have considered three important organs, namely, liver, kidney and spleen. In case of gold nanoparticles, Sonavane $e t$ al. (Sonavane $e t$ al., 2008) observed that smaller particles $(15 \mathrm{~nm})$ were able to penetrate into deeper layers and suggested that their permeation into blood streams can eventually spread all over the body (Sonavane et al., 2008). Metabolism and elimination of metal particles are equally important as are their distribution and accumulation studies. For metabolism and elimination, two of the most important organs that were considered are the liver and the kidney. Liver is the primary organ in absorbing the particles from the circulation and metabolizing them through the involvement of Kupffer cells while the role of kidney comes into play in the elimination of the particles from the body through urine. For the immunogenic response of the body against these particles, the spleen was taken as the primary site for the study of macrophage formation and deployment (Swirski et al., 2009; Kim et al., 2008). Histopathological analysis of these three organs through hematoxylin and eosin (HE) staining thus becomes imperative in studying their tissue morphology and cellular architecture. Toxicity profiling by hematological study and serum analyses of liver and kidney were also performed for this purpose.

\section{METHODS}

\section{Preparation of the gold-manganese oxide nano-composite particle}

The gold nanoparticles were prepared by using the Frens citrate reduction procedure (Rahaman et al., 2014). Goldmanganese oxide nanoparticles were synthesized at water $/ \mathrm{n}$ heptane interface under mild reflux conditions. $2.5 \mathrm{mM}$ $\mathrm{Mn}(\mathrm{ac})_{2} \cdot 4 \mathrm{H}_{2} \mathrm{O}$ was added in binary solvent mixture of water and nheptane $(3: 1 \mathrm{v} / \mathrm{v})$ and brought to reflux under stirring. After half an hour, ammonia was added and then the prepared gold nanoparticles were added drop wise under reflux. When the color of the solution changed to brownish red, the heating was stopped and the mixture was stirred for $12 \mathrm{~h}$ at room temperature. The particles were recovered from the solution by centrifuging at $10,000 \mathrm{rpm}$ for $15 \mathrm{~min}$ and dispersed in water. The most important advantage of this process is that the particles were prepared and were found to be stable at near physiological $\mathrm{pH}$ (Rahaman et al., 2014). Later, the particles were coated and stabilized with mouse serum albumin (MSA).

\section{Animals}

Male Swiss albino mice (Laca strain) were purchased from Pasteur Institute, Shillong, India, bearing license no. 34/DR/1966. The animals were 6-8 weeks old having body weight of $20 \pm 2 \mathrm{~g}$. The animals were housed in Departmental animal facility and conditions were provided following the guidelines prescribed by Institutional Ethical Committee (Assam University, Silchar, India). All the in vivo experiments were performed as per the IEC guidelines under the IEC approval no. IEC/AUS/B/2013$015 \mathrm{dt}-27 / 11 / 2013$.

\section{Experimental groups}

Total 25 mice were divided into 5 groups having 5 mice in each group. One group was kept as control and the other 4 groups were treated with 4 different doses $\left(1.3 \times 10^{-5}, 1.3 \times 10^{-4}\right.$, $1.3 \times 10^{-3}$ and $1.3 \times 10^{-2} \mathrm{mg} / \mathrm{kg}$ body weight of mouse respectively having corresponding particle numbers of $3.8 \times 10^{11}, 3.8 \times 10^{12}$, $3.8 \times 10^{13}$ and $3.8 \times 10^{14}$ ) of the nano-composite particles for 28 days on alternate days. The particles were administered subcutaneously in one of the flank regions. All the experiments were repeated thrice.

\section{Bio-distribution of nanoparticles}

At the end of 28 days treatment with the nanoparticles, all the mice including those of the control group were sacrificed on the $29^{\text {th }}$ day. Liver, kidney and spleen tissue from all the animals were recovered and $500 \mathrm{mg}$ of each organ was dissolved in aqua regia $(4 \mathrm{ml})$. The solution was heated up to $80^{\circ} \mathrm{C}$ to digest the tissue completely. The digested solutions were then diluted to a total volume of $10 \mathrm{ml}$ each. The amount of metal (nanoparticles) in the solution was quantified following the protocol of Sophisticated Analytical Instrument Facility (SAIF) at the Indian Institute of Technology, Bombay by inductively coupled plasma atomic emission spectroscopy (ICP-AES).

\section{Hematological analysis}

Whole blood was collected weekly from all the animals from lateral tail veins into EDTA coated vials. The whole blood was then analyzed using Piramal photometer 5010 V5+ autoanalyzer (Piramal Enterprise Limited). The different parameters for the analysis includes hemoglobin (HGB), leukocyte count (WBC), neutrophil count (N), lymphocyte count (LYM), monocyte count $(\mathrm{M})$, eosinophil count $(\mathrm{E})$, packed cell volume 
(PCV), mean corpuscular volume (MCV), mean corpuscular hemoglobin $(\mathrm{MCH})$, mean corpuscular hemoglobin content (MCHC), erythrocyte count (RBC) and platelet count (PLT).

\section{Serum analysis}

Blood was collected from treated as well as control groups and the serum was isolated from it. The collected serum was assayed for total cholesterol (TC), triglycerides (TG), creatinine, aspartate transferase (AST), alanine transferase (ALT), alkaline phosphatase (ALP), proteins, high density lipoprotein (HDL) and low density lipoprotein (LDL) using Piramal photometer 5010 V5+ auto-analyzer (Piramal Enterprise Limited).

\section{Histological analysis}

Histological analysis of organs like kidney, liver and spleen were performed to elucidate the effect of nanoparticles upon intravenous administration. At the end of the treatment, all the animals were sacrificed on the $29^{\text {th }}$ day. The above mentioned organs were collected in $10 \%$ formaldehyde solution at room temperature. The respective tissues were then processed and sliced using a microtome allowing a thickness of $5 \mu \mathrm{m}$. The prepared sections were then stained with hematoxylin and eosin.

\section{Statistical analysis}

All the experiments were done using five replicate samples and each experiment was repeated thrice and represented the data in Mean \pm SEM (standard error of mean). The significance levels for bioaccumulation assay were calculated by using Mann-Whitney $U$ test. The same test was performed to calculate the significance levels for hematological and serum assays and Kruskal-Wallis $\mathrm{H}$ test was performed for both dose and time effect. All the statistical calculations were done in SPSS v20 and data representations have been done in the GraphPad Prism 6 software.

\section{RESULTS}

\section{Preparation of the gold-manganese oxide nano-composite particle}

UV-VIS spectrum of gold nanoparticle, manganese oxide nanoparticle and the nanocomposites shows the respective characteristic peaks (Figure 1a) that confirms the formation of gold-manganese oxide nanocomposites. Figure $1 \mathrm{~b}$ shows the transmission electron micrograph of nanocomposites. IR spectrum of the MSA coated nanocomposite shows the characteristic bond formation required for better stability (Figure 1c). In case of MSA coated $\mathrm{Au}-\mathrm{Mn}_{3} \mathrm{O}_{4}$ nanocomposites, change in band positions with regard to that of free MSA was observed for bond stretching of $\mathrm{N}$ $\mathrm{H}, \mathrm{C}=\mathrm{O}$ and $\mathrm{C}-\mathrm{N}$ and the values have been tabulated in Table 1 . The energy dispersive X-ray (EDX) spectrum and selected area electron diffraction (SAED) pattern of $\mathrm{Au}-\mathrm{Mn}_{3} \mathrm{O}_{4}$ nanocomposites are shown in Figure 2. The EDX spectrum (Figure 2a) of Au$\mathrm{Mn}_{3} \mathrm{O}_{4}$ composites shows that the particles are composed of $\mathrm{Mn}$, $\mathrm{C}, \mathrm{O}, \mathrm{Cu}$ and $\mathrm{Au}$ elements. Among those elements, the signals of $\mathrm{Mn}, \mathrm{O}$ and $\mathrm{Au}$ result from the $\mathrm{Mn}_{3} \mathrm{O}_{4}$ and $\mathrm{Au}$ which comprises the product and the signals of $\mathrm{C}$ and $\mathrm{Cu}$ elements comes from the carbon-coated copper grid. The SAED pattern (Figure $2 b$ ) of the $\mathrm{Au}-\mathrm{Mn}_{3} \mathrm{O}_{4}$ composites exhibit a bright reflection from the (111) plane of fcc (face-centered cubic) structured gold and a strong ring pattern corresponding to (101), (103) and (211) planes of tetragonal hausmannite structure.

Table 1: Change in band positions for free MSA compared with that of MSA-AuMn ${ }_{3} \mathrm{O}_{4}$ for characteristic bond stretching in IR spectrum.

\begin{tabular}{|c|c|c|}
\hline \multirow{2}{*}{ Bond Stretching } & \multicolumn{2}{|c|}{ IR Spectrum } \\
\hline & $\operatorname{MSA}\left(\mathrm{cm}^{-1}\right)$ & MSA-AuMn ${ }_{3} \mathrm{O}_{4}\left(\mathrm{~cm}^{-1}\right)$ \\
\hline $\mathrm{N}-\mathrm{H}$ & 3285 & 3370 \\
\hline $\mathrm{C}=\mathrm{O}$ & 1620 & 1680 \\
\hline $\mathrm{C}-\mathrm{N}$ & 1520 & 1548 \\
\hline
\end{tabular}

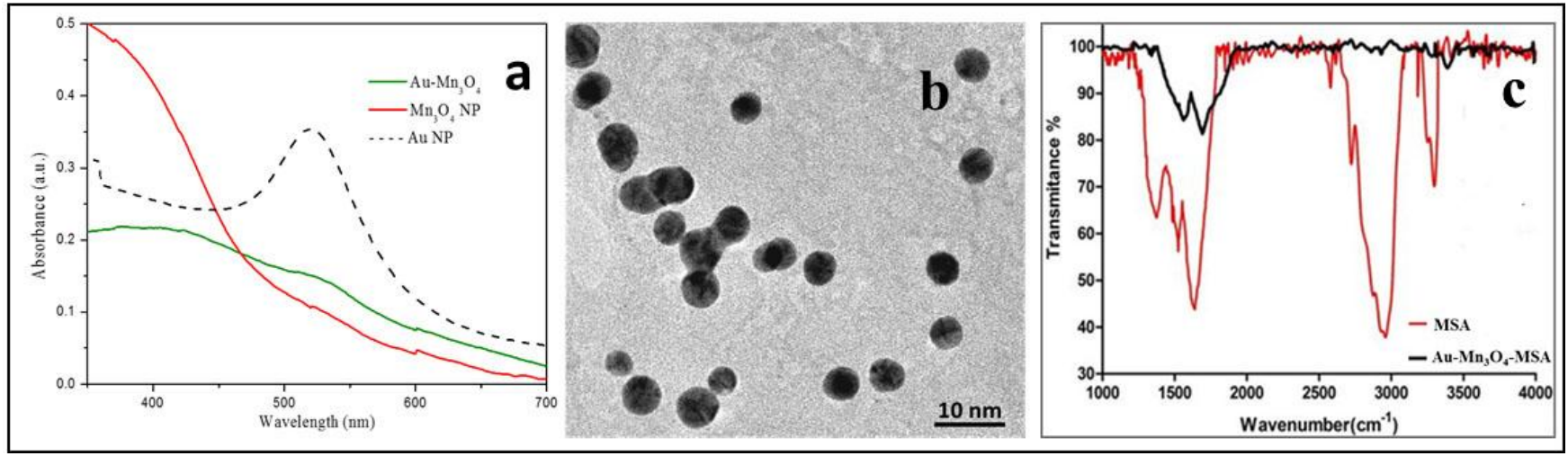

Fig. 1: Characterization of the nanocomposite was done through (a) UV-VIS spectrum of gold nanoparticle, manganese oxide nanoparticle and the nanocomposites showed the respective characteristic peaks that confirms the formation of gold-manganese oxide nanocomposites, (b) Transmission electron micrograph shows the spherical shape of the particles and size and functionalization with MSA is confirmed by (c) IR spectrum where characteristic change in bond positions are observed for $\mathrm{N}-\mathrm{H}$ stretching, $\mathrm{C}=\mathrm{O}$ stretching and $\mathrm{C}-\mathrm{N}$ stretching. 


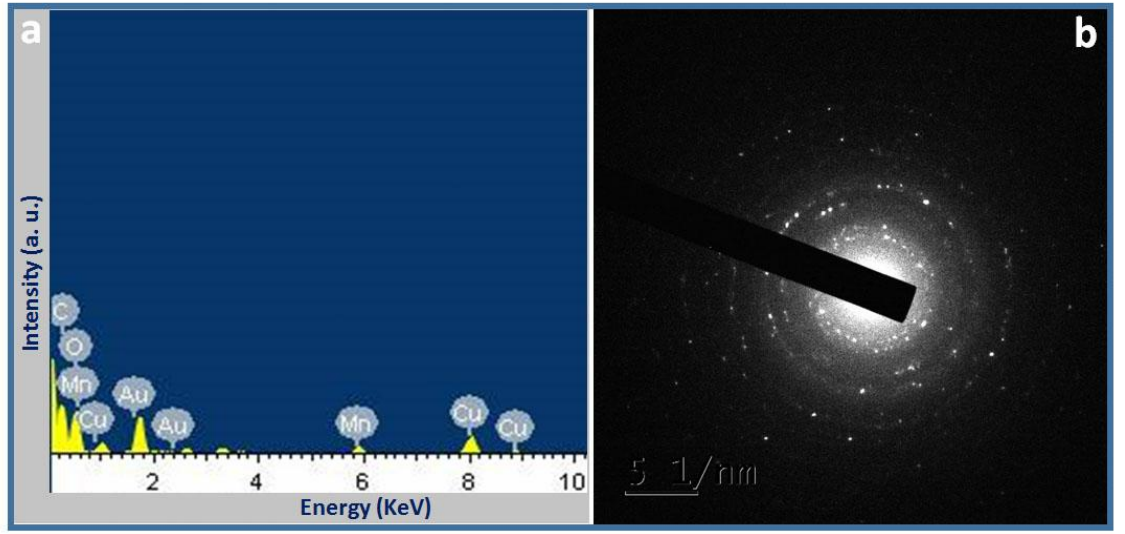

Fig. 2: (a) Energy dispersive X-ray (EDX) spectrum shows that the particles were composed of $\mathrm{Mn}, \mathrm{C}, \mathrm{O}, \mathrm{Cu}$ and Au elements. Apart from the core elements, the signals of $\mathrm{C}$ and $\mathrm{Cu}$ elements came from carbon-coated copper grid. (b) Selected area electron diffraction (SAED) pattern of $\mathrm{Au}^{-\mathrm{Mn}_{3} \mathrm{O}_{4} \text { nanocomposites }}$ shows a bright reflection from the (111) plane of fcc (face-centered cubic) structured gold and a strong ring pattern corresponding to (101), (103) and (211) planes of tetragonal hausmannite structure.

Table 2: Accumulation of nanocomposites in liver, kidney and spleen expressed in parts per millions (Mean \pm SEM) along with level of significance with control group.

\begin{tabular}{ccccccc} 
& \multicolumn{5}{c}{ Accumulation of particles in } \\
\cline { 2 - 7 } Treatments & \multicolumn{2}{c}{ Liver } & \multicolumn{2}{c}{ Kidney } & \multicolumn{2}{c}{ Spleen } \\
\cline { 2 - 7 } & ppm (Mean \pm SEM) & $\begin{array}{c}\text { Level of } \\
\text { significance with } \\
\text { control group }\end{array}$ & $\begin{array}{c}\text { ppm } \\
\text { (Mean } \pm \text { SEM) }\end{array}$ & $\begin{array}{c}\text { Level of } \\
\text { significance with } \\
\text { control group }\end{array}$ & $\begin{array}{c}\text { Level of } \\
\text { ppm }\end{array}$ & $\begin{array}{c}\text { (Mean } \pm \text { SEM) } \\
\text { significance with } \\
\text { control group }\end{array}$ \\
\hline Control & $0.067 \pm 0.0039$ & $\mathrm{~N} / \mathrm{A}$ & $0.057 \pm 0.0061$ & $\mathrm{~N} / \mathrm{A}$ & $0.029 \pm 0.0024$ & $\mathrm{~N} / \mathrm{A}$ \\
Dose 1 & $0.071 \pm 0.0021$ & $\mathrm{p}>0.05$ & $0.058 \pm 0.0027$ & $\mathrm{p}>0.05$ & $0.029 \pm 0.0017$ & $\mathrm{p}>0.05$ \\
Dose 2 & $0.068 \pm 0.0032$ & $\mathrm{p}>0.05$ & $0.071 \pm 0.0040$ & $\mathrm{P}<0.05$ & $0.029 \pm 0.0020$ & $\mathrm{p}>0.05$ \\
Dose 3 & $0.104 \pm 0.0058$ & $\mathrm{P}<0.0001$ & $0.080 \pm 0.0046$ & $\mathrm{P}<0.0001$ & $0.030 \pm 0.0017$ & $\mathrm{p}>0.05$ \\
Dose 4 & $0.126 \pm 0.0037$ & $\mathrm{P}<0.0001$ & $0.097 \pm 0.0072$ & $\mathrm{P}<0.0001$ & $0.031 \pm 0.0017$ & $\mathrm{p}>0.05$ \\
\hline
\end{tabular}

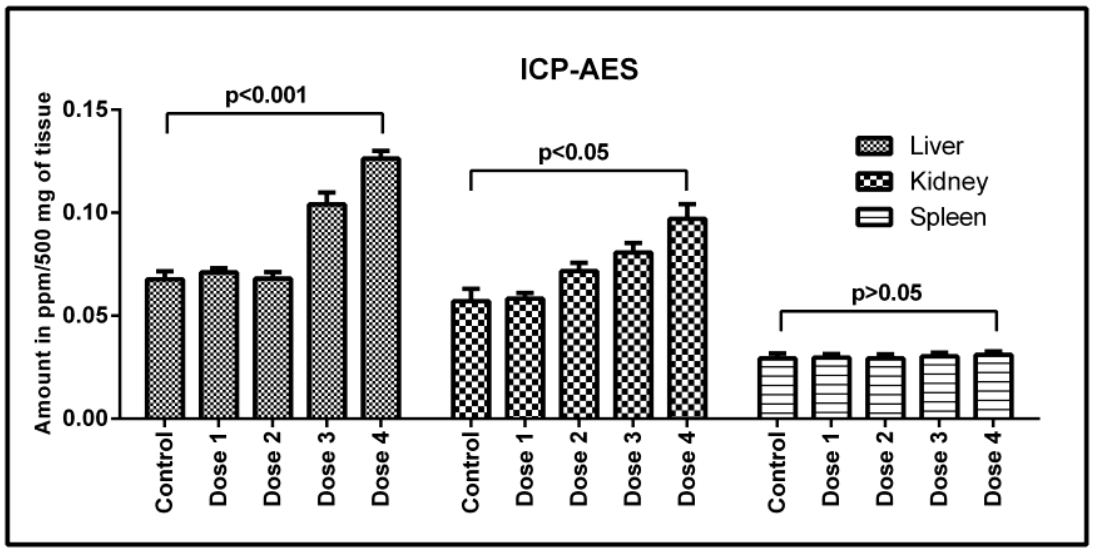

Fig. 3: Accumulation of nanoparticles in liver, kidney and spleen calculated through ICP-AES. Significant amount of particle accumulation is seen for liver and kidney. Accumulation in spleen is found insignificant when compared with that of the control group. Significant values for dose 3 and higher were found significantly higher $(\mathrm{p}<0.0001)$ for both liver and kidney than that of control groups. Statistical calculations were performed in SPSS v20 by using MannWhitney U test and the graph is plotted in GraphPad Prism 6 ('N' is the number of replica for each observation).

\section{Bio-distribution of nanoparticles}

In the liver, the first two doses showed almost same level of accumulation of manganese as of the control. But for doses 3 and 4 , the accumulation of manganese was significantly higher than that of the control group. In case of the kidney, the similarity of accumulation could be seen between control group, doses 1 and 2. Other two groups have shown significantly higher accumulation of the particles than that of the control group. These patterns cannot be seen in the case of spleen. Here accumulation was found to be uniform irrespective of the doses (Figure 3). Mean values of each observations for the accumulation of particles in liver, kidney and spleen along with their SEM values and level of significance with control group have been mentioned in Table 2. 


\section{Hematological analysis}

The dose effect of hematological treatment was found to be significant, as mentioned in Figure 4 while values for the time effect were found to be insignificant. WBC counts for dose 4 were found to be significantly higher than that of control throughout the treatment regime (Figure 4B).

Gradual increase in neutrophil levels has been seen in case of doses 3 and 4 (Figure 4C). At doses 3 and 4, MCH has also shown moderate but uniform increase in counts than that of control
(Figure 4D). On the other hand, HGB (Figure 4A) and RBC (Figure 4Ea) have shown gradual decrease in counts with increase in particle concentration and time. From $\mathrm{RBC}$ count, the $\mathrm{IC}_{50}$ value was calculated and was found to be $4.3 \times 10^{-4} \mathrm{mg} / \mathrm{kg}$ body weight of mouse (Figure 4Eb).

Mean values of each observation for all the parameters along with their respective SEM values and level of significance with the control groups have been tabulated in Table 3 .

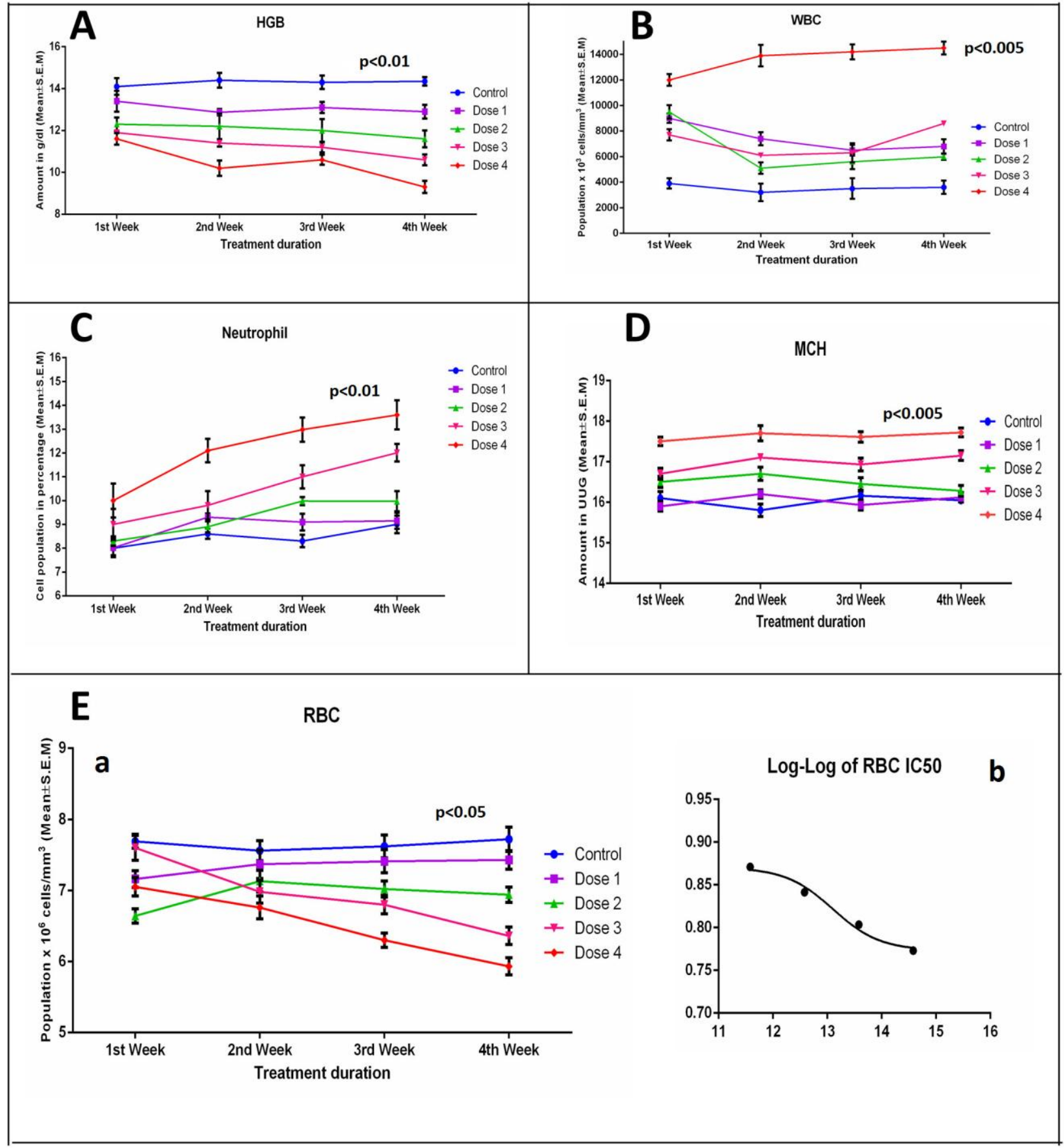

Fig. 4: The whole blood containing EDTA was analyzed using Piramal photometer 5010 V5+ auto-analyzer (Piramal Enterprise Limited). The obtained values are plotted in GraphPad Prism 6 for (A) hemoglobin count ( $<<0.01)$, (B) WBC count ( $<<0.01)$, (C) neutrophil count ( $<<0.05)$, (D) mean corpuscular hemoglobin value $(p<0.01)$ and $(\mathbf{E a})$ RBC count $(p<0.01)$ and $(\mathbf{E b})$ its normalized curve and the significant values are calculated for both dose and time effect. The calculations were done in SPSS v20 by using Kruskal-Wallis H test (' $N$ ' is the number of replica for each observation). 
Table 3: Hematological parameters for 5 experimental groups and 4 weeks expressed in Mean \pm SEM along with level of significance compared with the control group.

\begin{tabular}{|c|c|c|c|c|c|c|c|c|c|c|c|}
\hline \multirow[b]{2}{*}{ Dose } & \multirow[b]{2}{*}{ Period } & \multicolumn{2}{|c|}{ HGB } & \multicolumn{2}{|c|}{ WBC } & \multicolumn{2}{|c|}{ Neutrophil } & \multicolumn{2}{|c|}{ MCH } & \multicolumn{2}{|c|}{ RBC } \\
\hline & & $\begin{array}{c}\text { Mean } \\
\pm \text { SEM }\end{array}$ & $\begin{array}{c}\text { Significan } \\
\text { ce level }\end{array}$ & $\begin{array}{c}\text { Mean } \\
\pm \text { SEM }\end{array}$ & $\begin{array}{c}\text { Signific } \\
\text { ance } \\
\text { level }\end{array}$ & $\begin{array}{c}\text { Mean } \\
\pm \text { SEM }\end{array}$ & $\begin{array}{c}\text { Signifi } \\
\text { cance } \\
\text { level }\end{array}$ & $\begin{array}{c}\text { Mean } \\
\pm \text { SEM }\end{array}$ & $\begin{array}{c}\text { Signific } \\
\text { ance } \\
\text { level }\end{array}$ & $\begin{array}{c}\text { Mean } \\
\pm \text { SEM }\end{array}$ & $\begin{array}{c}\text { Signific } \\
\text { ance } \\
\text { level }\end{array}$ \\
\hline \multirow{4}{*}{ 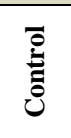 } & $1^{\text {st }}$ Week & $14.10 \pm 0.4$ & \multirow{4}{*}{ N/A } & $3900 \pm 400$ & \multirow{4}{*}{ N/A } & $8.00 \pm 0.3$ & \multirow{4}{*}{ N/A } & $16.10 \pm 0.164$ & \multirow{4}{*}{ N/A } & $7.69 \pm 0.098$ & \multirow{4}{*}{ N/A } \\
\hline & $2^{\text {nd }}$ Week & $14.40 \pm 0.35$ & & $3200 \pm 680$ & & $8.60 \pm 0.21$ & & $15.80 \pm 0.152$ & & $7.56 \pm 0.14$ & \\
\hline & $3^{\text {rd }}$ Week & $14.30 \pm 0.32$ & & $3500 \pm 803$ & & $8.30 \pm 0.26$ & & $16.16 \pm 0.108$ & & $7.62 \pm 0.16$ & \\
\hline & $4^{\text {th }}$ Week & $14.35 \pm 0.2$ & & $3600 \pm 517$ & & $9.00 \pm .037$ & & $16.05 \pm 0.086$ & & $7.72 \pm 0.17$ & \\
\hline \multirow{4}{*}{ 总 } & $1^{\text {st }}$ Week & $13.40 \pm 0.5$ & \multirow{4}{*}{$\mathrm{p}<0.01$} & $9000 \pm 362$ & \multirow{4}{*}{$\mathrm{p}<0.01$} & $8.02 \pm 0.401$ & \multirow{4}{*}{$\mathrm{p}>0.05$} & $15.90 \pm 0.120$ & \multirow{4}{*}{$\mathrm{p}<0.05$} & $7.16 \pm 0.118$ & \multirow{4}{*}{$\mathrm{p}<0.05$} \\
\hline & $2^{\text {nd }}$ Week & $12.87 \pm 0.15$ & & $7400 \pm 512$ & & $9.30 \pm 0.156$ & & $16.20 \pm 0.108$ & & $7.37 \pm 0.201$ & \\
\hline & $3^{\text {rd }}$ Week & $13.10 \pm 0.26$ & & $6500 \pm 426$ & & $9.10 \pm 0.35$ & & $15.93 \pm 0.128$ & & $7.41 \pm 0.162$ & \\
\hline & $4^{\text {th }}$ Week & $12.90 \pm 0.33$ & & $6800 \pm 556$ & & $9.15 \pm 0.34$ & & $16.12 \pm 0.115$ & & $7.43 \pm 0.13$ & \\
\hline \multirow{4}{*}{ 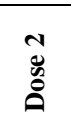 } & $1^{\text {st }}$ Week & $12.30 \pm 0.32$ & \multirow{4}{*}{$\mathrm{p}<0.01$} & $9500 \pm 526$ & \multirow{4}{*}{$\mathrm{p}<0.05$} & $8.30 \pm 0.198$ & \multirow{4}{*}{$\mathrm{p}>0.05$} & $16.50 \pm 0.14$ & \multirow{4}{*}{$\mathrm{p}<0.05$} & $6.64 \pm 0.099$ & \multirow{4}{*}{$\mathrm{p}<0.05$} \\
\hline & $2^{\text {nd }}$ Week & $12.20 \pm 0.61$ & & $5100 \pm 451$ & & $8.90 \pm 0.235$ & & $16.70 \pm 0.16$ & & $7.13 \pm 0.154$ & \\
\hline & $3^{\text {rd }}$ Week & $12.00 \pm 0.54$ & & $5600 \pm 586$ & & $9.98 \pm 0.167$ & & $16.45 \pm 0.153$ & & $7.02 \pm 0.114$ & \\
\hline & $4^{\text {th }}$ Week & $11.60 \pm 0.4$ & & $5980 \pm 236$ & & $9.97 \pm 0.425$ & & $16.28 \pm 0.136$ & & $6.94 \pm 0.108$ & \\
\hline \multirow{4}{*}{ 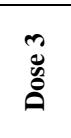 } & $1^{\text {st }}$ Week & $11.90 \pm 0.11$ & \multirow{4}{*}{$\mathrm{p}<0.01$} & $7700 \pm 442$ & \multirow{4}{*}{$\mathrm{p}<0.01$} & $9.00 \pm 0.648$ & \multirow{4}{*}{$\mathrm{p}<0.05$} & $16.70 \pm 0.14$ & & $7.60 \pm 0.175$ & \multirow{4}{*}{$\mathrm{p}>0.05$} \\
\hline & $2^{\text {nd }}$ Week & $11.40 \pm 0.16$ & & $6100 \pm 158$ & & $9.80 \pm 0.596$ & & $17.10 \pm 0.092$ & & $6.98 \pm 0.162$ & \\
\hline & $3^{\text {rd }}$ Week & $11.20 \pm 0.24$ & & $6300 \pm 751$ & & $11.00 \pm 0.488$ & & $16.93 \pm 0.16$ & $\mathrm{p}>0.05$ & $6.80 \pm 0.132$ & \\
\hline & $4^{\text {th }}$ Week & $10.60 \pm 0.26$ & & $8600 \pm 152$ & & $12.01 \pm 0.369$ & & $17.15 \pm 0.12$ & & $6.36 \pm 0.124$ & \\
\hline \multirow{4}{*}{$\begin{array}{l}\dot{\Xi} \\
\stackrel{\mathscr{D}}{0}\end{array}$} & $1^{\text {st }}$ Week & $11.60 \pm 0.28$ & \multirow{4}{*}{$\mathrm{p}<0.01$} & $12000 \pm 456$ & & $10.00 \pm 0.71$ & & $17.50 \pm 0.1$ & & $7.05 \pm 0.13$ & \\
\hline & $2^{\text {nd }}$ Week & $10.20 \pm 0.36$ & & $13900 \pm 843$ & & $12.10 \pm 0.49$ & & $17.70 \pm 0.19$ & & $6.76 \pm 0.16$ & \\
\hline & $3^{\text {rd }}$ Week & $10.60 \pm 0.24$ & & $14200 \pm 587$ & $\mathrm{p}<0.001$ & $12.98 \pm 0.51$ & $\mathrm{p}<0.01$ & $17.61 \pm 0.13$ & $\mathrm{p}<0.01$ & $6.30 \pm 0.1$ & $\mathrm{p}<0.05$ \\
\hline & $4^{\text {th }}$ Week & $9.30 \pm 0.29$ & & $14500 \pm 497$ & & $13.60 \pm 0.61$ & & $17.72 \pm 0.11$ & & $5.93 \pm 0.12$ & \\
\hline
\end{tabular}

Table 4A: Lipid profile parameters for 5 experimental groups and 4 weeks expressed in Mean \pm SEM along with level of significance compared with the control group.

\begin{tabular}{|c|c|c|c|c|c|c|c|}
\hline \multirow[b]{2}{*}{ Dose } & \multirow[b]{2}{*}{ Period } & \multicolumn{2}{|c|}{ Cholesterol } & \multicolumn{2}{|c|}{ LDL } & \multicolumn{2}{|c|}{ TG } \\
\hline & & Mean \pm SEM & $\begin{array}{c}\text { Significance } \\
\text { level }\end{array}$ & Mean \pm SEM & $\begin{array}{c}\text { Significance } \\
\text { level }\end{array}$ & Mean \pm SEM & $\begin{array}{c}\text { Significance } \\
\text { level }\end{array}$ \\
\hline \multirow{4}{*}{$\begin{array}{l}\overline{0} \\
\text { 苛 }\end{array}$} & $1^{\text {st }}$ Week & $94 \pm 3$ & \multirow{4}{*}{ N/A } & $28 \pm 1.36$ & \multirow{4}{*}{ N/A } & $75 \pm 3$ & \multirow{4}{*}{ N/A } \\
\hline & $2^{\text {nd }}$ Week & $94 \pm 2.8$ & & $30 \pm 1.98$ & & $75 \pm 2$ & \\
\hline & $3^{\text {rd }}$ Week & $93 \pm 6$ & & $31 \pm 2.02$ & & $75 \pm 5$ & \\
\hline & $4^{\text {th }}$ Week & $94 \pm 5$ & & $30 \pm 1.99$ & & $74 \pm 4$ & \\
\hline \multirow{4}{*}{$\begin{array}{l}\overrightarrow{0} \\
\tilde{D} \\
\stackrel{0}{0}\end{array}$} & $1^{\text {st }}$ Week & $89 \pm 4$ & \multirow{4}{*}{$p>0.05$} & $31 \pm 2.36$ & \multirow{4}{*}{$\mathrm{p}<0.05$} & $69 \pm 3.21$ & \multirow{4}{*}{$\mathrm{p}>0.05$} \\
\hline & $2^{\text {nd }}$ Week & $95 \pm 7$ & & $32 \pm 2.54$ & & $92 \pm 3.98$ & \\
\hline & $3^{\text {rd }}$ Week & $96 \pm 4.2$ & & $33 \pm 2.89$ & & $96 \pm 4.28$ & \\
\hline & $4^{\text {th }}$ Week & $99 \pm 3.98$ & & $31 \pm 2.58$ & & $105 \pm 5.06$ & \\
\hline \multirow{4}{*}{$\begin{array}{l}\sim \\
0 \\
\infty \\
0\end{array}$} & $1^{\text {st }}$ Week & $88 \pm 4$ & \multirow{4}{*}{$\mathrm{p}>0.05$} & $26 \pm 2.96$ & \multirow{4}{*}{$\mathrm{p}>0.05$} & $65 \pm 4.32$ & \multirow{4}{*}{$\mathrm{p}>0.05$} \\
\hline & $2^{\text {nd }}$ Week & $99 \pm 3.96$ & & $28 \pm 3.2$ & & $83 \pm 4.99$ & \\
\hline & $3^{\text {rd }}$ Week & $107 \pm 5$ & & $30 \pm 3.04$ & & $99 \pm 3.63$ & \\
\hline & $4^{\text {th }}$ Week & $103 \pm 4.12$ & & $33 \pm 3.44$ & & $103 \pm 4.91$ & \\
\hline \multirow{4}{*}{$\begin{array}{l}m \\
0 \\
\infty \\
\stackrel{0}{0}\end{array}$} & $1^{\text {st }}$ Week & $113 \pm 6.1$ & \multirow{4}{*}{$\mathrm{p}<0.001$} & $43 \pm 4.09$ & \multirow{4}{*}{$\mathrm{p}<0.01$} & $89 \pm 3.36$ & \multirow{4}{*}{$\mathrm{p}<0.05$} \\
\hline & $2^{\text {nd }}$ Week & $116 \pm 4.3$ & & $40 \pm 4.52$ & & $113 \pm 4.07$ & \\
\hline & $3^{\text {rd }}$ Week & $119 \pm 6$ & & $42 \pm 3.98$ & & $14.9420 \pm 4.94$ & \\
\hline & $4^{\text {th }}$ Week & $120 \pm 8.6$ & & $38 \pm 4.87$ & & $122 \pm 5.6$ & \\
\hline \multirow{4}{*}{ 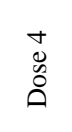 } & $1^{\text {st }}$ Week & $118 \pm 6.2$ & \multirow{4}{*}{$\mathrm{p}<0.001$} & $48 \pm 2.9$ & \multirow{4}{*}{$\mathrm{p}<0.01$} & $93 \pm 4.01$ & \multirow{4}{*}{$\mathrm{p}<0.05$} \\
\hline & $2^{\text {nd }}$ Week & $111 \pm 7.19$ & & $45 \pm 2.54$ & & $161 \pm 3.99$ & \\
\hline & $3^{\text {rd }}$ Week & $123 \pm 4$ & & $50 \pm 2.04$ & & $169 \pm 6.5$ & \\
\hline & $4^{\text {th }}$ Week & $125 \pm 4.48$ & & $52 \pm 2.91$ & & $175 \pm 4.3$ & \\
\hline
\end{tabular}

\section{Serum analysis}

The dose effect of serum treatment was found to be significant, as mentioned in Figure 5, while values for the time effect were found to be insignificant. Cholesterol, TG and LDL have shown marked increase in their levels for doses 3 and 4. Cholesterol levels for doses 3 and 4 have shown significant increase throughout the treatment than that of control group (Figure 5A). Significantly high level of TG has been observed for dose 4 than that of control (Figure 5C).

In case of LDL also, high level could be observed for dose 4 at $4^{\text {th }}$ week (Figure 5B). Though the level of HDL was found to be decreasing, its changes were not significant with control group. Liver function tests like SGOT (Figure 5E), SGPT (Figure 5F) and ALP (Figure 5D) showed high levels for dose 4 as compared with control group. Creatinine, which is a marker of kidney functioning, also showed elevated levels as compared with the control (Figure 5G). Mean values of each observation for all the parameters of lipid profile tests along with their respective SEM values and level of significance with the control groups have been mentioned in Table 4A and that of liver and kidney function tests have been tabulated in Table 4B. 


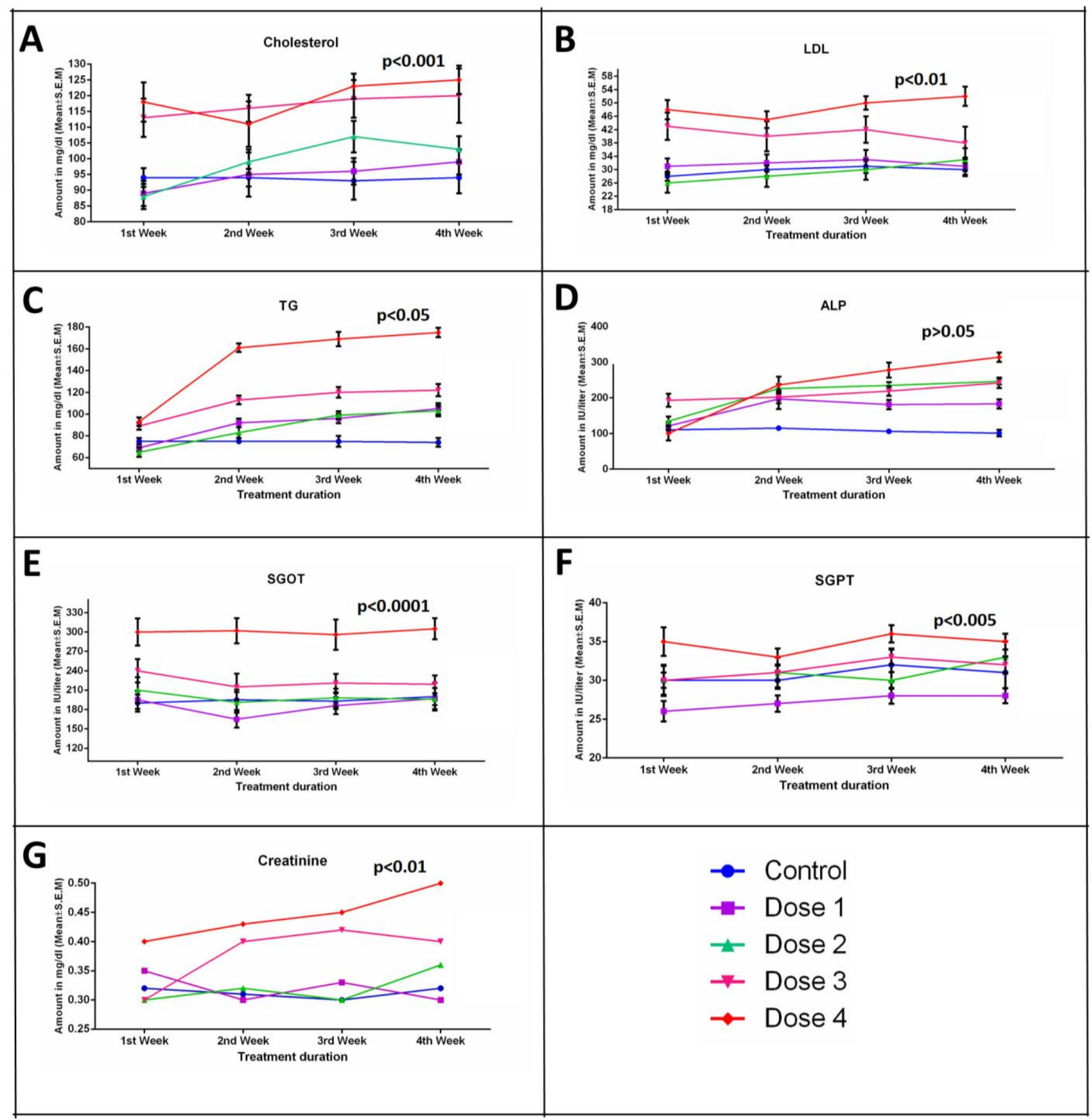

Fig. 5: The collected serum was analyzed using Piramal photometer 5010 V5+ auto-analyzer (Piramal Enterprise Limited). The obtained values are plotted in GraphPad Prism 6 for (A) cholesterol (p<0.01), (B) LDL (p<0.01), (C) TG (p<0.05), (D) ALP (p>0.05), (E) SGOT $(\mathrm{p}<0.01)$, (F) SGPT $(\mathrm{p}<0.01)$ and $(\mathbf{G})$ Creatinine $(\mathrm{p}<0.05)$. The significant values are calculated for both dose and time effect. The calculations were done in SPSS v20 by using Kruskal-Wallis H test (' $N$ ' is the number of replica for each observation). 
Table 4B: Liver and kidney function parameters for 5 experimental groups and 4 weeks expressed in Mean \pm SEM along with level of significance compared with the control group.

\begin{tabular}{|c|c|c|c|c|c|c|c|c|c|}
\hline \multirow[b]{2}{*}{ Dose } & \multirow[b]{2}{*}{ Period } & \multicolumn{2}{|c|}{$\overline{\mathbf{A L P}}$} & \multicolumn{2}{|c|}{ SGOT } & \multicolumn{2}{|c|}{$\overline{\text { SGPT }}$} & \multicolumn{2}{|c|}{ Creatinine } \\
\hline & & $\begin{array}{c}\text { Mean } \\
\pm \text { SEM }\end{array}$ & $\begin{array}{l}\text { Significa } \\
\text { nce level }\end{array}$ & $\begin{array}{c}\text { Mean } \\
\pm \text { SEM }\end{array}$ & $\begin{array}{c}\text { Significanc } \\
\text { e level }\end{array}$ & $\begin{array}{c}\text { Mean } \\
\pm \text { SEM }\end{array}$ & $\begin{array}{l}\text { Significa } \\
\text { nce level }\end{array}$ & $\begin{array}{c}\text { Mean } \\
\pm \text { SEM }\end{array}$ & $\begin{array}{c}\text { Significance } \\
\text { level }\end{array}$ \\
\hline \multirow{4}{*}{$\begin{array}{l}\overline{0} \\
\stackrel{\Xi}{0} \\
\text { U }\end{array}$} & $1^{\text {st }}$ Week & $110 \pm 6.05$ & \multirow{4}{*}{ N/A } & $190 \pm 13.2$ & \multirow{4}{*}{ N/A } & $30 \pm 2.01$ & \multirow{4}{*}{ N/A } & $0.32 \pm 0.003$ & \multirow{4}{*}{ N/A } \\
\hline & $2^{\text {nd }}$ Week & $115 \pm 6.41$ & & $195 \pm 15.7$ & & $30 \pm 1.098$ & & $0.31 \pm 0.001$ & \\
\hline & $3^{\text {rd }}$ Week & $106 \pm 4.52$ & & $193 \pm 12.09$ & & $32 \pm 2.09$ & & $0.30 \pm 0.001$ & \\
\hline & $4^{\text {th }}$ Week & $101 \pm 9.3$ & & $200 \pm 21.5$ & & $31 \pm 2.003$ & & $0.32 \pm 0.002$ & \\
\hline \multirow{4}{*}{$\begin{array}{l}\overrightarrow{0} \\
\infty \\
0 \\
0\end{array}$} & $1^{\text {st }}$ Week & $121 \pm 11.09$ & \multirow{4}{*}{$\mathrm{p}<0.05$} & $195 \pm 14.08$ & \multirow{4}{*}{$p>0.05$} & $26 \pm 1.32$ & & $0.35 \pm 0.001$ & \multirow{4}{*}{$p>0.05$} \\
\hline & $2^{\text {nd }}$ Week & $197 \pm 28.3$ & & $165 \pm 13$ & & $27 \pm 1.05$ & & $0.30 \pm 0.001$ & \\
\hline & $3^{\text {rd }}$ Week & $181 \pm 13.078$ & & $186 \pm 12.98$ & & $28 \pm 1.029$ & $\mathrm{p}<0.01$ & $0.33 \pm 0.001$ & \\
\hline & $4^{\text {th }}$ Week & $183 \pm 12.97$ & & $197 \pm 16.3$ & & $28 \pm 0.97$ & & $0.30 \pm 0.001$ & \\
\hline \multirow{4}{*}{$\begin{array}{l}v \\
\tilde{D} \\
0 \\
0\end{array}$} & $1^{\text {st }}$ Week & $134 \pm 13.09$ & \multirow{4}{*}{$\mathrm{p}<0.05$} & $210 \pm 19.84$ & \multirow{4}{*}{$\mathrm{p}>0.05$} & $30 \pm 1.86$ & & $0.30 \pm 0.001$ & \multirow{4}{*}{$\mathrm{p}>0.05$} \\
\hline & $2^{\text {nd }}$ Week & $226 \pm 11.98$ & & $191 \pm 16.02$ & & $31 \pm 1.93$ & & $0.32 \pm 0.001$ & \\
\hline & $3^{\text {rd }}$ Week & $235 \pm 9.24$ & & $198 \pm 14.26$ & & $30 \pm 1.068$ & $p>0.05$ & $0.30 \pm 0.001$ & \\
\hline & $4^{\text {th }}$ Week & $246 \pm 8.31$ & & $196 \pm 9.26$ & & $33 \pm 2.007$ & & $0.36 \pm 0.001$ & \\
\hline \multirow{4}{*}{ 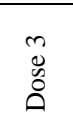 } & $1^{\text {st }}$ Week & $193 \pm 18.3$ & \multirow{4}{*}{$\mathrm{p}<0.01$} & $240 \pm 18.2$ & \multirow{4}{*}{$\mathrm{p}<0.05$} & $30 \pm 0.986$ & & $0.30 \pm 0.001$ & \multirow{4}{*}{$\mathrm{p}>0.05$} \\
\hline & $2^{\text {nd }}$ Week & $202 \pm 17.56$ & & $215 \pm 20.4$ & & $31 \pm 1.025$ & ᄀ & $0.40 \pm 0.001$ & \\
\hline & $3^{\text {rd }}$ Week & $219 \pm 13.54$ & & $221 \pm 14.27$ & & $33 \pm 0.99$ & $\mathrm{p}>0.05$ & $0.42 \pm 0.001$ & \\
\hline & $4^{\text {th }}$ Week & $242 \pm 14.6$ & & $219 \pm 13.87$ & & $32 \pm 1.088$ & & $0.40 \pm 0.001$ & \\
\hline \multirow{4}{*}{$\begin{array}{l}+ \\
0 \\
0 \\
0 \\
0\end{array}$} & $1^{\text {st }}$ Week & $100 \pm 19.73$ & \multirow{4}{*}{$\mathrm{p}>0.05$} & $300 \pm 21$ & \multirow{4}{*}{$\mathrm{p}<0.0001$} & $35 \pm 1.84$ & & $0.40 \pm 0.001$ & \multirow{4}{*}{$\mathrm{p}<0.01$} \\
\hline & $2^{\text {nd }}$ Week & $236 \pm 23.5$ & & $302 \pm 19.6$ & & $33 \pm 1.09$ & 0 & $0.43 \pm 0.001$ & \\
\hline & $3^{\text {rd }}$ Week & $278 \pm 21.089$ & & $296 \pm 23.5$ & & $36 \pm 1.121$ & $p<0.01$ & $0.45 \pm 0.003$ & \\
\hline & $4^{\text {th }}$ Week & $314 \pm 12.99$ & & $305 \pm 16.4$ & & $35 \pm 1.03$ & & $0.50 \pm 0.003$ & \\
\hline
\end{tabular}

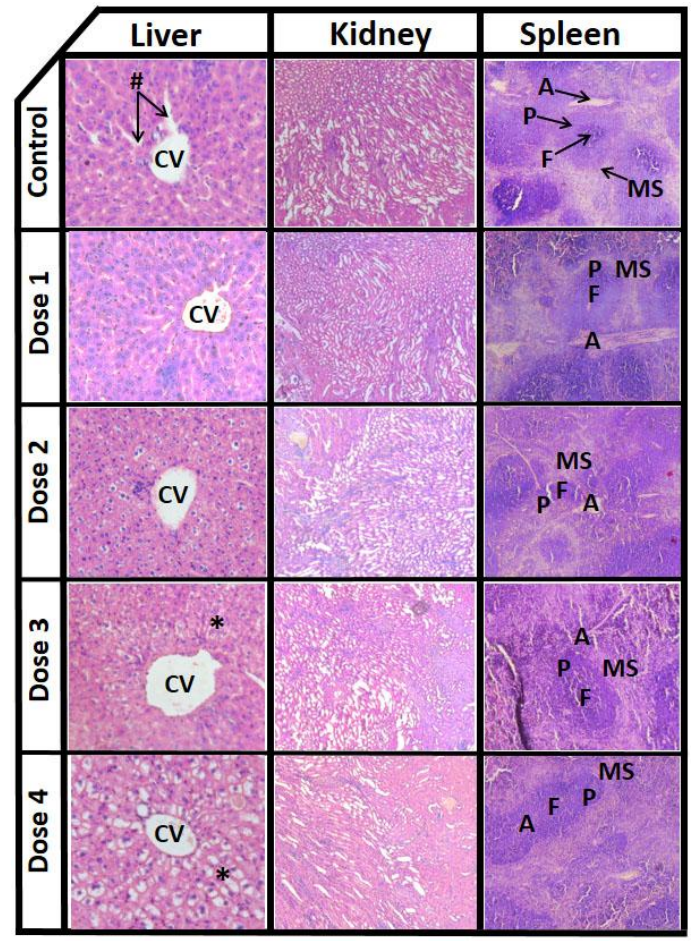

Fig. 6: HE stained slides of liver, kidney and spleen for control and all the doses. \# shows the chords of hepatocytes radiating from the central vein (CV) and * represents steatosis. None of the doses have shown any perceivable change in renal ultrastructure. In all the groups, the spleen sections show pronounced marginal sinus region (MS) with demarcations of the follicle (F) from the periartiolar lymphoid sheaths (P). 'A' denotes central artery.

\section{Histological analysis}

Prepared slides were observed under bright field microscope to analyze the tissue morphology. In case of liver, dose 1 and 2 showed normal tissue morphology as that of the control group. But in case of dose 3 and 4 some sort of main artery damage can be seen. Kidney samples did not show any deformities for all the doses. Spleen also showed a similar pattern and did not show any abnormalities in tissue morphology (Figure 6).

\section{DISCUSSION}

Several studies report the toxicity profiling of individual gold and manganese, both as bulk material or nanoparticles (Gerber et al., 2013; Persellin et al., 1967; Schlumpf et al., 1983; Zaitseva et al., 2015; Alkilany and Murphy, 2010; Choi et al., 
2009; Vijayakumar and Ganesan, 2012; Raja et al., 2010). Moreover, most of these are in vitro studies (Alkilany and Murphy, 2010; Choi et al., 2009; Vijayakumar and Ganesan, 2012) with reports on their effects in vivo very rare (Gerber et al., 2013). Thus, toxicity-profiling of a novel gold-manganese nanocomposite in an in vivo model, as done in the present study, is one of the first reports of its kind. The nanocomposite used in this study was a chimeric combination of gold and manganese oxide in the ratio of 1:9 $(\mathrm{w} / \mathrm{w})$. Besides their catalytic activities, gold nanoparticles are also important for their surface plasmon resonance (SPR) property. But the SPR property, being a surface phenomenon, cannot be used for detecting the particles in vivo. Therefore in this study, gold nanoparticles have been coupled with manganese oxide nanoparticles to enhance the MRI signature of the nanocomposite. Because of the higher MRI signature, this composite can be used under in vivo conditions.

The particles were coated with MSA to minimize the reactivity of the nanoparticle metal surface with other biomolecules in the blood stream. Albumin was chosen over other proteins as it is the most abundant protein in the blood stream. Though it was established that albumin is highly conserved among mammalian species, we have chosen to use albumin only of murine origin. This precautionary measure was taken to nullify the probable immunogenicity that could have occurred from albumin of species other than that of murine origin (Chakraborty et al., 2016). The gold-manganese oxide nano-composites were prepared at a final concentration in the order of $10^{-3} \mathrm{M}$, thus making the concentration of $2.6 \times 10^{-4} \mathrm{mg} / \mathrm{ml}$ (Rahaman et al., 2014). Therefore in this study, we have taken this dose as the highest one and made a 10 fold serial dilution thereof, to get the least dose of $2.6 \times 10^{-7} \mathrm{mg}$.

The efficacy of nanoparticles largely depend on their half-life period in the blood stream and inside the body, whereas, their toxicity primarily depends on their accumulation in the vital organs and other body parts. ICP-AES is a technique that detects dissolved metals in a given sample. The spectroscopic method measures the absorbance of a given metal present in the solution. In the study, accumulation of only manganese has been shown for all the tissue samples. The reason for this is that gold was present in the composite along with manganese oxide in the ratio of 1:9 causing it to go undetected. Accumulation of manganese as seen in the control group was mainly because of the water source that was supplied to the mice during the treatment regime. When we look for accumulation of particles in the liver, the first two groups and the control group have shown almost similar levels while dose 3 and 4 have shown significantly higher accumulation. Effect of this accumulation can be also seen from the serum analyses results. Triglycerides are the compounds that increase in response to any liver damage due to the presence of toxic substance, temporary or chronic.

The metal nanoparticles at a relatively higher dose could cause liver damage reflected by a concomitant increase in the triglyceride levels. This finding was also supported by the serum levels of both HDL and LDL. LDL was found to be elevated at the higher doses (3 and 4) while HDL levels fall, indicative of atherosclerosis accompanied by an increase in leukocyte count. Interestingly, when we considered HE stained slides of liver, the tissue morphology was found to be normal in doses 1 and 2 only. For doses 3 and 4 there were abnormalities in the central vein and hepatic parenchyma and clear indication of steatosis/fat deposition was seen.

In the kidney, significant metal accumulation has been seen in an increasing order with increase of doses from dose 2 to dose 4. In spite of the accumulation, the creatinine level of the blood has been observed to be elevated significantly only in case of dose 4, which is a marker of kidney function abnormality. Tissue samples for all the doses looked normal morphologically.

Mean corpuscular hemoglobin $(\mathrm{MCH})$ is the average amount of hemoglobin present inside a RBC, whose level is measured by calculating the total hemoglobin count divided by total RBC count. The high level of $\mathrm{MCH}$ is an indication of macrocytic anemia which may be due to compromise of liver function. At dose 4, both RBC and hemoglobin counts were decreased but average hemoglobin count per RBC was increased significantly. From the results it can be seen that the changes in case of MCHC was insignificant despite the increased level of $\mathrm{MCH}$. It is due to the fact that $\mathrm{MCHC}$ is the ratio of $\mathrm{MCH}$ and $\mathrm{MCV}$ and the result does not show any significant difference in the MCV level.

With the decreasing amount of $\mathrm{RBC}$ count, the $\mathrm{IC}_{50}$ value was calculated and it was found to be $4.3 \times 10^{-4} \mathrm{mg} / \mathrm{kg}$ body weight of mouse. This value lies below dose 3 and signifies less toxicity of the nano-composite at lower doses.

\section{CONCLUSION}

By comparing all the above described parameters, it could be concluded that doses 1 and 2 are the doses at which no or very minimal negative effects can be seen. Theoretically, any dose below the $\mathrm{IC}_{50}$ value can be used safely for in vivo experiments. In our study, we have standardized the dose for in vivo treatment so that further in vivo experiments can be done using a value much lower than that of $\mathrm{IC}_{50}$ value. For further experiments, therefore we may use a dose whose value is closer to dose 1 . Throughout the study, it can be concluded that dose 1 is the dose where all the vital organs have shown normal functioning; accumulation of the particles was also found to be under considerable limits for all the vital organs and the tissue morphology appeared normal.

\section{ACKNOWLEDGEMENT}

We would like to acknowledge, University Grant Commission, India for the BSR fellowship of research scholars, Anupam Nath and Himadri Saikia; Assam University (Silchar) Non-NET fellowships for Ramkrishna Pal and Leichombam Mohindro Singh; Pasteur Institute, Shillong, India for supplying Swiss albino mice; Sophisticated and Analytical Instruments Facility (SAIF), Indian Institute of Technology, Mumbai, India for ICP-AES experiment. 
Conflict of Interests: There are no conflicts of interest.

\section{REFERENCES}

Alkilany AM, Murphy CJ. Toxicity and cellular uptake of gold nanoparticles: what we have learned so far? Journal of Nanoparticle Research, 2010; 12:2313-2333.

Chakraborty B, Pal R, Ali M, Singh LM, Shahidur Rahman D, Kumar Ghosh S, Sengupta M. Immunomodulatory properties of silver nanoparticles contribute to anticancer strategy for murine fibrosarcoma. Cell Mol Immunol, 2016; 13:191-205.

Chen J, Han CM, Lin XW, Tang ZJ, Su SJ. [Effect of silver nanoparticle dressing on second degree burn wound]. Zhonghua Wai $\mathrm{Ke}$ Za Zhi, 2006; 44:50-52.

Choi JY, Lee SH, Na HB, An K, Hyeon T, Seo TS. In vitro cytotoxicity screening of water-dispersible metal oxide nanoparticles in human cell lines. Bioprocess and Biosystems Engineering, 2009; 33:21.

Gerber A, Bundschuh M, Klingelhofer D, Groneberg DA. Gold nanoparticles: recent aspects for human toxicology. Journal of Occupational Medicine and Toxicology (London, England), 2013; 8:3232.

Huh Y-M, Jun Y-w, Song H-T, Kim S, Choi J-s, Lee J-H, Yoon S, Kim K-S, Shin J-S, Suh J-S, Cheon J. In Vivo Magnetic Resonance Detection of Cancer by Using Multifunctional Magnetic Nanocrystals. Journal of the American Chemical Society, 2005; 127:12387-12391.

Johnston HJ, Hutchison G, Christensen FM, Peters S, Hankin S, Stone V. A review of the in vivo and in vitro toxicity of silver and gold particulates: Particle attributes and biological mechanisms responsible for the observed toxicity. Critical Reviews in Toxicology, 2010; 40:328-346.

Johnston HJ, Hutchison GR, Christensen FM, Peters S, Hankin $\mathrm{S}$, Stone V. Identification of the mechanisms that drive the toxicity of $\mathrm{TiO} 2$ particulates: the contribution of physicochemical characteristics. Particle and Fibre Toxicology, 2009; 6:33.

Kim YS, Kim JS, Cho HS, Rha DS, Kim JM, Park JD, Choi BS, Lim R, Chang HK, Chung YH, Kwon IH, Jeong J, Han BS, Yu IJ. Twenty-Eight-Day Oral Toxicity, Genotoxicity, and Gender-Related Tissue Distribution of Silver Nanoparticles in Sprague-Dawley Rats. Inhalation Toxicology, 2008; 20:575-583.

Maynard AD, Aitken RJ, Butz T, Colvin V, Donaldson K, Oberdorster G, Philbert MA, Ryan J, Seaton A, Stone V, Tinkle SS, Tran L, Walker NJ, Warheit DB. Safe handling of nanotechnology. Nature, 2006; 444:267-269.

Mokari T, Rothenberg E, Popov I, Costi R, Banin U. Selective Growth of Metal Tips onto Semiconductor Quantum Rods and Tetrapods. Science, 2004; 304:1787.

Pal R, Chakraborty B, Nath A, Singh LM, Ali M, Rahman DS, Ghosh SK, Basu A, Bhattacharya S, Baral R, Sengupta M. Noble metal nanoparticle-induced oxidative stress modulates tumor associated macrophages (TAMs) from an M2 to M1 phenotype: An in vitro approach. International Immunopharmacology, 2016; 38:332-341.
Persellin RH, Hess EV, Ziff M. Effect of a gold salt on the immune response. Arthritis Rheum, 1967; 10:99-106.

Rahaman H, Barman K, Jasimuddin S, Ghosh SK. Bifunctional gold-manganese oxide nanocomposites: benign electrocatalysts toward water oxidation and oxygen reduction. RSC Advances, 2014; 4:4197641981 .

Raja GR, Wilma P, Liesbeth H, Patrick C, Hans J, Fijs WBvL, Cees O, Srirang M, Ton GvL. In vitro toxicity studies of polymer-coated gold nanorods. Nanotechnology, 2010; 21:145101.

Schlumpf U, Meyer M, Ulrich J, Friede RL. Neurologic complications induced by gold treatment. Arthritis \& Rheumatism, 1983; 26:825-831.

Shi W, Sahoo Y, Zeng H, Ding Y, Swihart MT, Prasad PN. Anisotropic Growth of PbSe Nanocrystals on $\mathrm{Au}-\mathrm{Fe} 3 \mathrm{O} 4$ Hybrid Nanoparticles. Advanced Materials, 2006; 18:1889-1894.

Sonavane G, Tomoda K, Sano A, Ohshima H, Terada H, Makino K. In vitro permeation of gold nanoparticles through rat skin and rat intestine: Effect of particle size. Colloids and Surfaces B: Biointerfaces, 2008; 65:1-10.

Soppimath KS, Aminabhavi TM, Kulkarni AR, Rudzinski WE. Biodegradable polymeric nanoparticles as drug delivery devices. Journal of Controlled Release, 2001; 70:1-20.

Swirski FK, Nahrendorf M, Etzrodt M, Wildgruber M, CortezRetamozo V, Panizzi P, Figueiredo JL, Kohler RH, Chudnovskiy A, Waterman P, Aikawa E, Mempel TR, Libby P, Weissleder R, Pittet MJ. Identification of splenic reservoir monocytes and their deployment to inflammatory sites. Science, 2009; 325:612-616.

Vijayakumar S, Ganesan S. In Vitro Cytotoxicity Assay on Gold Nanoparticles with Different Stabilizing Agents. Journal of Nanomaterials, 2012; 2012:9.

Yu H, Liu X, Xing R, Liu S, Li C, Li P. Radical scavenging activity of protein from tentacles of jellyfish Rhopilema esculentum. Bioorganic \& Medicinal Chemistry Letters, 2005; 15:2659-2664.

Zaitseva NV, Zemlyanova MA, Zvezdin VN, Akafieva TI, Saenko EV. Acute inhalation toxicity of manganese oxide nanoparticles. Nanotechnologies in Russia, 2015; 10:468-474.

How to cite this article:

Nath A, Pal R, Singh LM, Saikia H, Rahaman H, Ghosh SK, Mazumder R, Sengupta M. Dose Response Study of A Novel GoldManganese Oxide Nano-Composite In An In Vivo Murine Model. J App Pharm Sci, 2017; 7 (12): 028-037. 